\title{
Electric to acoustic pitch matching: a possible way to improve individual cochlear implant fitting
}

Walter Di Nardo • Italo Cantore • Maria Raffaella Marchese • Francesca Cianfrone •

Alessandro Scorpecci · Sara Giannantonio • Gaetano Paludetti

Published online: 17 April 2008

(C) Springer-Verlag 2008

Erratum to: Eur Arch Otorhinolaryngol

DOI: 10.1007/s00405-008-0655-3

In the affiliations section at the bottom of the title page, the first author's name was abbreviated incorrectly. W.D. Nardo should be W. Di Nardo.

The online version of the original article can be found under doi: 10.1007/s00405-008-0655-3.

W. Di Nardo $(\varangle) \cdot$ I. Cantore · M. R. Marchese · F. Cianfrone

A. Scorpecci · S. Giannantonio - G. Paludetti

Institute of Otorhinolaryngology,

Catholic University of the Sacred Heart,

A. Gemelli University Hospital, Largo Gemelli,

8, 00168 Rome, Italy

e-mail: dinardow@libero.it 